\title{
Adoptive immunotherapy for pancreatic cancer: Cytotoxic T lymphocytes stimulated by the MUC1-expressing human pancreatic cancer cell line YPK-1
}

\author{
TORU KAWAOKA, MASAAKI OKA, MOTONARI TAKASHIMA, \\ TOMIO UENO, KOUTARO YAMAMOTO, NOBORU YAHARA, \\ SHIGEFUMI YOSHINO and SHOICHI HAZAMA
}

\begin{abstract}
Department of Digestive Surgery and Surgical Oncology (Department of Surgery II), Yamaguchi University Graduate School of Medicine, 1-1-1 Minamikogushi, Ube, Yamaguchi 755-8505, Japan
\end{abstract}

Received December 27, 2007; Accepted March 21, 2008

\begin{abstract}
MUC1 is a tumor-associated antigen that is overexpressed in invasive ductal carcinomas of the pancreas (PC). MUC1-specific cytotoxic T lymphocytes (CTLs) recognize MUC1 molecules in a HLA-unrestricted manner. In this study, we performed adoptive immunotherapy (AIT) in patients with PC with CTLs stimulated by the MUC1expressing human PC cell line YPK-1. To induce CTLs, peripheral blood mononuclear cells (PBMCs) were cultured for 3 days with inactivated YPK-1 cells and then stimulated with interleukin (IL)-2 for 7 days. The cytotoxicity of these cells against human cancer cell lines was analyzed, and a variety of antibodies were evaluated for their ability to inhibit cytotoxicity. We treated 8 patients with unresectable PC and 20 patients with resectable PC postsurgically. CTLs were induced as described above, suspended in $100 \mathrm{ml}$ saline and injected intravenously. Induced CTLs were cytotoxic against 5 MUC1-expressing PC cell lines and a breast cancer cell line, regardless of the HLA phenotype. Low cytotoxicity was observed in 7 MUC1-negative cancer cell lines. Anti-CD3 monoclonal antibody ( $\mathrm{mAb}$ ) or anti-CD8 mAb strongly inhibited cytotoxicity against YPK-1, whereas anti-class I $\mathrm{mAb}$ showed no inhibition. YPK-1 cells incubated with anti-MUC1 mAb also showed low cytotoxicity. Clinically, the median survival time was 5.0 months for patients with unresectable PC treated with AIT. None of the 5 patients without liver metastasis showed hepatic recurrence. The median survival time was 17.8 months for 18 out of 20
\end{abstract}

Correspondence to: Dr Masaaki Oka, Department of Digestive Surgery and Surgical Oncology (Department of Surgery II), Yamaguchi University Graduate School of Medicine, 1-1-1 Minamikogushi, Ube, Yamaguchi 755-8505, Japan

E-mail: 2geka-1@yamaguchi-u.ac.jp

Key words: MUC1, cytotoxic T lymphocytes, immunotherapy, pancreatic cancer patients with resectable PC who underwent curative surgery, and the 1-, 2- and 3-year survival rates after surgery were $83.3,32.4$, and $19.4 \%$, respectively. Liver metastasis was found in only one patient and no side effects of AIT were observed. CTLs stimulated by a MUC1-expressing human pancreatic cancer cell line showed a strong tumor cytotoxic activity in a MUC1-specific and MHC-unrestricted manner. AIT with stimulated CTLs significantly suppressed the postsurgical hepatic recurrence of PC. Adjuvant immunotherapy with CTLs may be useful in the postsurgical treatment of PC.

\section{Introduction}

Pancreatic cancer (PC) has the poorest prognosis among gastrointestinal cancers because of its low resectability, malignant behavior and low sensitivity to anticancer agents (1). Treatments for PC, including surgery, chemotherapy and radiotherapy, have failed to improve its prognosis $(2,3)$. Metastasis to the liver is the most important factor underlying poor prognosis. New treatment strategies are therefore necessary.

Immunotherapy has an advantage over radiation therapy and chemotherapy because it can act specifically against the tumor without damaging normal tissue. Immunotherapeutic approaches to PC have included the use of monoclonal antibodies (4-7), cytokines (8), vaccine (9) and lymphokineactivated killer (LAK) cells (10). We reported on the efficacy of adoptive immunotherapy (AIT) with cytotoxic T lymphocytes (CTLs), induced from autologous pancreatic tumors but not from AIT with LAK cells (11). Although these immunotherapies have a potential as alternative treatments for PC, the effects have been limited.

Mucins are large glycoproteins that are expressed by a variety of normal and malignant epithelial cells (12). Although at least 16 different mucin polypeptides (apomucins), MUC116 , have been identified in human tissues (13), MUC1 is unique in its transmembrane expression at the cell surface (14). Cancer-associated MUC1 is incompletely glycosylated, with truncated carbohydrate chains composed largely of 1-6 sugar units (15). As a result of incomplete glycosylation, cancerassociated MUC1 possesses exposed internal sugar units and 
naked peptide sequences that are cryptic in the normal mucin molecule (16). CTLs against MUC1 have been induced in patients with pancreatic, breast or ovarian cancer (17-19). Notably, unlike conventional CTLs, these CTLs recognize MUC1 molecules in a HLA-unrestricted manner. It has been proposed that normally cryptic CTL epitopes in the MUC1 core protein are unmasked by underglycosylation in tumor cells and that highly multivalent epitopes of tandemly repeated peptides on a single MUC1 molecule crosslink the T cell receptors (TCRs) of anti-MUC1 CTLs (16). Such immune responses against MUC1 may be useful for immunotherapy. It has been reported that MUC1 apomucin is the major type of mucin in invasive ductal carcinoma of the pancreas (20-23). Therefore, MUC1 may serve as a target antigen for the treatment of PC. We have reported on the use of AIT with CTLs induced from a MUC1-expressing human PC cell line, YPK-1, for unresectable PC $(24,25)$. The objective of this study was to further analyze CTLs stimulated by YPK-1 cells and to evaluate the clinical efficacy of AIT with this type of CTL for unresectable and resectable PC.

\section{Materials and methods}

Cell lines. Human cancer cell lines used in the experimental study were: PC cell lines YPK-1, -2, -3 and -4, Panc 1 and MIA PaCa 2; the breast cancer cell line YMMK-1 and the esophageal cancer cell lines YES-1, -2, -3, -4, -5 and -6. YPK-1, -2, -3 and -4; YMMK-1 and the 6 esophageal cancer cell lines were established in our department. Panc1 and MIA $\mathrm{PaCa} 2$ cell lines were obtained from the Health Science Research Resources Bank, Osaka, Japan. All cell lines were maintained in Dulbecco's modified Eagle's medium (DMEM) (Nissui Pharmaceutical Co., Ltd., Tokyo, Japan) containing $10 \%$ fetal bovine serum (FBS) (Sigma-Aldrich, St. Louis, $\mathrm{MO}$ ) in $5 \% \mathrm{CO}_{2}$. MUC1 expression and HLA typing for each cell line are detailed in Table I.

CTL induction. We used peripheral blood mononuclear cells (PBMCs) obtained from a healthy volunteer, with HLA-A phenotype 24/26. Cells were cultured in serum-free medium (A1M-V) (Gibco, Paisley, Scotland) with the MUC1expressing pancreatic cancer cell line YPK-1 (HLA-A phenotype 24/02) inactivated with $0.2 \mathrm{mg} / \mathrm{ml}$ mitomycin $\mathrm{C}$ (Kyowa Hakko Kogyo Co., Ltd., Tokyo, Japan). The effector to target cell ratio was 1000:1. After 3 days, the cells were cultured with 10 Japan Reference Unit (JRU)/ml interleukin (IL)-2 (Shionogi Pharmaceutical Co., Tokyo, Japan) in a $\mathrm{CO}_{2}$ incubator for 7 days. The cells induced were used as effector cells.

Cytotoxicity assay. Target cells $\left(1 \times 10^{6} / \mathrm{ml}\right)$ were labeled for $60 \mathrm{~min}$ at $37^{\circ} \mathrm{C}$ with $100 \mu \mathrm{Ci} / \mathrm{ml}$ radioactive sodium chromate $\left({ }^{51} \mathrm{Cr}\right)$ (Amersham Japan, Tokyo, Japan). The cells were then washed 4 times in RPMI-1640 medium (Sigma-Aldrich). Labeled cells were resuspended in culture medium $\left(1 \times 10^{5} / \mathrm{ml}\right)$. Effector cells consisting of induced CTLs were suspended at $0.5,1.0$ or $2.0 \times 10^{6} / \mathrm{ml}$. Effector cell suspension $(0.1 \mathrm{ml})$ was added to a microplate (Falcon Plastics, Cockeysville, MD) with $0.1 \mathrm{ml}$ target cells, to yield an effector to target cell ratio of $5: 1,10: 1$ or $20: 1$. All experiments were performed in triplicate. Plates were incubated for $4 \mathrm{~h}$ at $37^{\circ} \mathrm{C}$ in a $\mathrm{CO}_{2}$ incubator. The amount of ${ }^{51} \mathrm{Cr}$ released into each well was determined with a $\gamma$ counter (Auto Well Gamma System ARC202, Aloka, Tokyo, Japan). The percentage of cytotoxicity was calculated as follows:

$\%$ cytotoxicity $=\frac{\text { experimental release }- \text { spontaneous release }}{\text { maximum release }- \text { spontaneous release }}$

To measure the spontaneous ${ }^{51} \mathrm{Cr}$ release of target cells in the absence of effector cells, target cells were mixed with $0.1 \mathrm{ml}$ culture medium. To obtain maximal a ${ }^{51} \mathrm{Cr}$ release, target cells were treated with $0.1 \mathrm{ml} 0.1 \mathrm{~N}$ hydrochloric acid.

Antibody inhibition of cytotoxicity. Anti-CD3, -CD4, -CD8 and anti-class I monoclonal antibodies $(\mathrm{mAb})$ (each diluted at 1:50) were used for blocking assays and were purchased from Dako Corp., Carpinteria, CA. The MUC1-expressing pancreatic cancer cell line YPK-1 was used as the target cell. Effector cells consisting of induced CTLs were incubated with $\mathrm{mAb}$ at the indicated concentrations for $45 \mathrm{~min}$ at $37^{\circ} \mathrm{C}$, washed 3 times in RPMI-1640 medium and suspended at $2 \times 10^{6} / \mathrm{ml}$. Target cells were labeled with ${ }^{51} \mathrm{Cr}$ as described above, washed 4 times and resuspended in culture medium $\left(1 \times 10^{5} / \mathrm{ml}\right)$. Effector cell suspension $(0.1 \mathrm{ml})$ was added with $0.1 \mathrm{ml}$ target cells to yield a 20:1 effector to target cell ratio for cytotoxicity assays as described above.

For anti-MUC1 mAb blocking, target cells were preincubated for $1 \mathrm{~h}$ at $37^{\circ} \mathrm{C}$ with anti-MUC1 mAb MY.1E12 (diluted at 1:200), kindly provided by Dr Tatsuo Irimura, Department of Cancer Biology and Molecular Immunology, Faculty of Pharmaceutical Sciences, University of Tokyo, Japan. Cytotoxicity assays were performed as described above.

Analysis of CTL subsets. Induced CTL subsets were analyzed with the use of mAbs against surface antigens of human lymphocytes. All mAbs were purchased from Coulter Immunology (Hialeah, FL). Fluorescein isothiocyanate (FITC)-conjugated anti-CD3 (T3), -CD4 (T4), -CD20 (B1), -CD25 (IL-2R1), -CD56 (NKH-1), -HLA-DR (I2) and antiCD11b (MO1) were used. Phycoerythrin (PE)-conjugated anti-CD8 (T8) and TQ1 (cluster unknown) were also used. A two-color analysis was performed with a combination of TQ1/CD4 (suppressor-inducer T and helper T cell) and CD8/ CD11b (cytotoxic T and suppressor T cell). Samples were analyzed with an EPICS flow cytometer (Coulter Electronics, Inc., Hialeah, FL) at a fluorescence excitation wavelength of $488 \mathrm{~nm}$ at 200-500 $\mathrm{mW}$. For each sample, 5000 lymphocytes were analyzed.

Patients with unresectable PC. During the period 1995-1997, we treated 8 patients with unresectable PC who had not undergone chemotherapy (Table II). The treatment was performed at the Department of Digestive Surgery and Surgical Oncology (Department of Surgery II), Yamaguchi University Graduate School of Medicine. Three patients showed liver metastasis and three showed peritoneal dissemination. Two patients showed lung metastasis but no liver metastasis or peritoneal dissemination. TNM staging according to the UICC (26) was IV for all patients, and all 
Table I. Cytotoxicities of CTLs stimulated by the MUC1-expressing human pancreatic cancer cell line, YPK-1, against a variety of human cancer cell lines.

\begin{tabular}{|c|c|c|c|c|c|}
\hline \multirow[b]{2}{*}{ Cancer cell lines } & \multirow{2}{*}{$\begin{array}{l}\text { MUC1- } \\
\text { expression }\end{array}$} & \multicolumn{3}{|c|}{ HLA typing } & \multirow{2}{*}{$\begin{array}{c}\text { Cytotoxicity (\%) } \\
\text { E:T }=20: 1\end{array}$} \\
\hline & & A & B & $\mathrm{Cw}$ & \\
\hline \multicolumn{6}{|l|}{ Pancreas } \\
\hline YPK-1 & + & $24 / 02$ & $46 / 01$ & 03/- & 49.0 \\
\hline YPK-2 & + & $24 / 02$ & $39 / 03$ & $12 /-$ & 47.3 \\
\hline YPK-3 & + & $02 / 01$ & $13 / 48$ & 03/08 & 56.8 \\
\hline YPK-4 & + & $26 / 10$ & $40 /-$ & $03 /-$ & 49.6 \\
\hline Panc-1 & + & $02 / 11$ & $38 / 01$ & $12 / 03$ & 54.3 \\
\hline MIA PACA 2 & - & $24 / 02$ & $46 / 01$ & 03/- & 10.0 \\
\hline \multicolumn{6}{|l|}{ Breast } \\
\hline YMMK-1 & + & $\mathrm{NE}$ & $\mathrm{NE}$ & $\mathrm{NE}$ & 41.2 \\
\hline \multicolumn{6}{|l|}{ Esophagus } \\
\hline YES-1 & - & $02 / 01$ & $15 / 11$ & 03/- & 14.8 \\
\hline YES-2 & - & $24 /-$ & $40 / 01$ & 03/07 & 18.4 \\
\hline YES-3 & - & $24 / 04$ & $15 / 01$ & $01 /-$ & 17.3 \\
\hline YES-4 & - & $24 / 02$ & $39 / 01$ & 07/- & 7.2 \\
\hline YES-5 & - & $02 / 01$ & $15 / 11$ & $03 /-$ & 11.8 \\
\hline YES-6 & - & $24 / 02$ & $15 / 01$ & 03/04 & 8.1 \\
\hline
\end{tabular}

Table II. Characteristics and survival of the patients with unresectable pancreatic cancer.

\begin{tabular}{lcccccccc}
\hline $\begin{array}{c}\text { Age } \\
\text { No. }\end{array}$ & (years) & Gender & Location & T & H & P & $\begin{array}{c}\text { Cell no. of } \\
\text { CTLs (x10 })\end{array}$ & $\begin{array}{c}\text { Survival } \\
\text { M }\end{array}$ \\
\hline 1 & 53 & $\mathrm{M}$ & $\mathrm{Pbt}$ & $\mathrm{T} 4$ & - & + & 28.0 & 5 \\
2 & 50 & $\mathrm{M}$ & $\mathrm{Pb}$ & $\mathrm{T} 2$ & - & + & 15.0 & 7 \\
3 & 59 & $\mathrm{M}$ & $\mathrm{Pbt}$ & $\mathrm{T} 4$ & + & - & 10.0 & 4 \\
4 & 65 & $\mathrm{M}$ & $\mathrm{Pbt}$ & $\mathrm{T} 3$ & + & - & 0.6 & 8 \\
5 & 73 & $\mathrm{M}$ & $\mathrm{Ph}$ & $\mathrm{T} 2$ & + & - & 5.0 & 3 \\
6 & 49 & $\mathrm{M}$ & $\mathrm{Ph}$ & $\mathrm{T} 3$ & - & + & 4.0 & 8 \\
7 & 61 & $\mathrm{M}$ & $\mathrm{Ph}$ & $\mathrm{T} 3$ & - & - & 18.0 & 3 \\
8 & 62 & $\mathrm{M}$ & $\mathrm{Ph}$ & $\mathrm{T} 3$ & - & - & 12.0 & 3 \\
\hline
\end{tabular}

$\mathrm{Ph}$, head of the pancreas, $\mathrm{Pb}$, body of the pancreas; Pbt, body and tail of the pancreas; $\mathrm{T}$, primary tumor stage; $\mathrm{H}$, liver metastasis and $\mathrm{P}$, peritoneal dissemination. TNM staging according to the UICC was IV for all patients. The HLA-A phenotypes of all patients were not checked.

showed histologically confirmed invasive ductal carcinoma of the pancreas.

Patients with resectable PC. During the period 1997-2004, we treated 20 patients with resectable PC postsurgically. Patient characteristics and treatment are detailed in Table III. TNM stages according to the UICC (26) for these patients were between IA and IIB, and their HLA-A phenotype varied.
Resection was performed in the absence of hematogenous metastases, peritoneal dissemination, gross retroperitoneal tumor infiltration and complex vascular infiltration. A limited invasion of the portal or superior mesenteric veins was regarded as an indication for portal vein resection. All patients received pancreatoduodenectomy (PD), pylorus preserving pancreatoduodenectomy (PPPD) or distal pancreatectomy (DP) with extended retroperitoneal lymphadenectomy. Of the 
Table III. Characteristics and treatment of the patients with resectable pancreatic cancer.

\begin{tabular}{lccccccc}
\hline No. & Age (years) & Gender & HLA-A & TNM stage & Operation & Resection of portal vein & IORT \\
\hline 1 & 66 & F & $24 / 02$ & IA & DP & - & + \\
2 & 73 & F & $02 / 01$ & IIA & PPPD & - & - \\
3 & 66 & M & $24 / 02$ & IIB & DP & - & - \\
4 & 45 & F & $24 / 02$ & IIA & PPPD & + & + \\
5 & 73 & M & $24 / 02$ & IIB & DP & - & + \\
6 & 69 & F & $26 / 01$ & IIB & PD & + & + \\
7 & 55 & M & $11 / 33$ & IIB & PPPD & - & + \\
8 & 72 & F & $02 /-$ & IIB & PPPD & + & + \\
9 & 66 & M & $02 / 31$ & IIB & PD & - & + \\
10 & 59 & M & $24 / 31$ & IIB & PD & + & + \\
11 & 60 & M & $02 / 11$ & IIB & DP & + & + \\
12 & 68 & M & $02 / 31$ & IIB & PD & + & + \\
13 & 67 & F & $11 / 26$ & IIB & PD & + & + \\
14 & 67 & M & $26 /-$ & IIB & PD & + & + \\
15 & 54 & M & $02 / 24$ & IIB & DP & + & - \\
16 & 71 & F & $24 /-$ & IIA & PD & - & - \\
17 & 78 & M & $02 /-$ & IIB & PD & - & - \\
18 & 72 & M & $02 / 24$ & IB & PPPD & - & - \\
19 & 60 & M & $26 / 31$ & IB & DP & PD & - \\
20 & 69 & F & $02 / 26$ & IIB & - & + \\
\hline
\end{tabular}

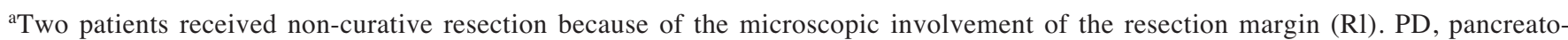
duodenectomy; PPPD, pylorus preserving pancreatoduodenectomy; DP, distal pancreatectomy and IORT, intraoperative radiotherapy. TNM staging is according to the UICC.

patients who underwent resection of the portal vein, 7 out of 8 showed histological invasion. Eighteen patients underwent curative resection (R0). Two patients underwent non-curative resection, because the microscopic involvement of the resection margin (R1) was found. All patients had histologically confirmed invasive ductal carcinoma. Histological classifications were: well-differentiated adenocarcinoma for 4 patients, moderately for 13 patients, poorly for 1 patient and mucinous carcinoma for 2 patients. Intraoperative radiation (20-30 Gy) therapy was performed in 11 cases in which retroperitoneal tumor infiltration was suspected.

CTL induction. PBMCs were harvested with the COBE Spectra Apheresis System (COBE BCT, Inc., Lakewood, CO). CTLs were expanded from these PBMCs as described above, and cultures were checked for bacterial contamination. Induced CTLs were washed once, suspended in $100 \mathrm{ml}$ saline and administered intravenously.

Schedule of AIT using CTLs: Patients with unresectable PC. CTLs were administered 1-11 times and the total number of CTLs administered were between $0.6 \times 10^{9}$ and $2.8 \times 10^{10}$ (Table II). This study protocol was approved by the Institutional Review Board for Human Use at the Yamaguchi University School of Medicine in 1995. Written informed consent was obtained from all patients. Tumors were evaluated by computed tomography $(\mathrm{CT})$, magnetic resonance imaging (MRI) or autopsy.

Patients with resectable PC. CTLs were induced before surgery and administered intravenously within a week after surgery. After the patient recovery from surgery, CTLs were re-induced and administered several times. The total number of CTLs administered are shown in Table IV. Eight patients were treated twice; six, 3 times; two, 4 times; two, 5 times; one patient was treated 6 times and one, 8 times. The total number of CTLs administered were between $5.0 \times 10^{8}$ and $2.5 \times 10^{10}$. The treatment of 16 patients was completed within 2 months after surgery, that of 2 patients was completed within 3 months after surgery and that of 2 patients was completed within 4 months after surgery. Recurrence was evaluated by CT, MRI or autopsy. None of the patients received chemotherapy. This study protocol was approved by the Institutional Review Board for Human Use at the Yamaguchi University School of Medicine in 1997. Written informed consent was obtained from all patients.

Statistical analysis. Changes in surface markers were assessed using Student's t-test for paired or unpaired means. A P-value of $<0.05$ was considered significant. Values are presented as 
Table IV. Total number and times of CTL transfer, recurrence sites and survival for the patients with resectable pancreatic cancer.

\begin{tabular}{|c|c|c|c|c|c|c|c|}
\hline \multirow{3}{*}{$\frac{\text { No. }}{1}$} & \multirow{3}{*}{$\frac{\text { Total cell no. }\left(\times 10^{9}\right)}{2.7}$} & \multirow{3}{*}{$\frac{\text { Times of transfer }}{3}$} & \multicolumn{2}{|c|}{ Recurrence sites } & \multirow[b]{2}{*}{ Other } & \multirow{2}{*}{\multicolumn{2}{|c|}{ Survival }} \\
\hline & & & \multirow{2}{*}{$\begin{array}{c}\text { Liver } \\
-\end{array}$} & \multirow{2}{*}{$\frac{\text { Local }}{+}$} & & & \\
\hline & & & & & - & $27 \mathrm{M}$ & Deceased \\
\hline 2 & 25.0 & 4 & - & + & - & $24 \mathrm{M}$ & Deceased \\
\hline 3 & 15.0 & 2 & - & - & Lung, bone & $13 \mathrm{M}$ & Deceased \\
\hline 4 & 12.0 & 4 & - & + & - & $21 \mathrm{M}$ & Deceased \\
\hline 5 & 6.0 & 3 & - & + & Lung, bone & $20 \mathrm{M}$ & Deceased \\
\hline $6^{\mathrm{a}}$ & 0.7 & 2 & - & + & - & $4 \mathrm{M}$ & Deceased \\
\hline 7 & 2.4 & 8 & - & + & Peritoneum & $15 \mathrm{M}$ & Deceased \\
\hline 8 & 2.2 & 5 & - & + & Lymph nodes & $16 \mathrm{M}$ & Deceased \\
\hline 9 & 2.7 & 5 & - & - & - & $74 \mathrm{M}$ & Alive \\
\hline 10 & 1.1 & 2 & - & - & - & $35 \mathrm{M}$ & Alive \\
\hline 11 & 0.7 & 3 & - & + & - & $16 \mathrm{M}$ & Deceased \\
\hline 12 & 0.6 & 2 & + & + & - & $6 \mathrm{M}$ & Deceased \\
\hline 13 & 1.0 & 2 & - & - & - & $49 \mathrm{M}$ & Alive \\
\hline 14 & 0.8 & 2 & - & + & Peritoneum & $15 \mathrm{M}$ & Deceased \\
\hline 15 & 1.8 & 3 & - & + & Peritoneum & $9 \mathrm{M}$ & Deceased \\
\hline 16 & 0.5 & 2 & - & - & Bone & $15 \mathrm{M}$ & Deceased \\
\hline 17 & 3.6 & 3 & - & + & - & $9 \mathrm{M}$ & Alive \\
\hline 18 & 11.0 & 6 & - & - & - & $20 \mathrm{M}$ & Alive \\
\hline 19 & 3.6 & 2 & - & + & Peritoneum & $12 \mathrm{M}$ & Deceased \\
\hline 20 & 6.6 & 3 & - & - & Lymph nodes & $14 \mathrm{M}$ & Deceased \\
\hline
\end{tabular}

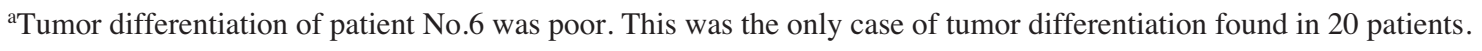

mean \pm SE. A Kaplan-Meier analysis was used to estimate the cumulative survival.

\section{Results}

CTL cytotoxicity. CTLs were cytotoxic against 5 MUC1expressing PC cell lines and 1 breast cancer cell line regardless of the HLA phenotype (Table I). Low cytotoxicity was observed against 7 MUC1-negative cancer cell lines, including the PC cell line MIA PACA 2 and 6 esophageal cancer cell lines. CTL cytotoxicity against PC cell lines (YPK-1 and -3) and esophageal cancer cell lines (YES-1 and -2) is shown in Fig. 1. Cytotoxicity was MHC-unrestricted and clearly decreased with the decreasing effector cell number.

Antibody inhibition of cytotoxicity. Anti-CD3 mAb or antiCD8 mAb inhibited CTL cytotoxicity against YPK-1 cells (Fig. 2). Anti-MUC1 mAb also inhibited cytotoxicity in these cells. Anti-class I mAb showed no inhibition of CTL cytotoxicity (E:T = 20:1; anti-CD3, 66.5\%; -CD4, 26.9\%; -CD8, 76.9\%; anti-class I, $11.8 \%$ and anti-MUC1, 64.1\%).

Patients with unresectable PC. AIT with CTLs did not improve the median survival time (MST) in patients with unresectable PC. MST was 5.0 months (Table II). None of the 5 patients without liver metastasis developed liver metastasis and no side effects of AIT with CTLs were observed.

Patients with resectable PC. The survival rate of 18 out of 20 PC patients that underwent curative resection is shown in Fig. 3. The survival time ranged from 4 to 74 months, and MST was 17.8 months. One-, 2- and 3-year survival rates after resection were $83.3,32.4$ and $19.4 \%$, respectively. No side effects of AIT with CTLs were observed. Liver metastasis was found in only 1 patient $(5.0 \%)$ and local recurrence was found in 13 patients $(65.0 \%)$ (Table IV).

Changes of lymphocyte subsets before and after the culture of PBMCs are detailed in Table $\mathrm{V}$. The proportions of $\mathrm{CD}^{+}, \mathrm{CD}^{+}$, suppressor-inducer $\mathrm{T}$ and cytotoxic $\mathrm{T}$ cells increased significantly after treatment $(\mathrm{P}<0.05)$, whereas the proportions of IL-2 receptor-positive, CD56+ (NK cells), HLA$\mathrm{DR}^{+}$and suppressor $\mathrm{T}$ cells decreased significantly $(\mathrm{P}<0.05)$.

\section{Discussion}

Despite intensive efforts by many groups to improve the efficacy of conventional chemotherapy or chemoradiotherapy for PC, little progress has been made $(2,3)$. In Japan, PC is the fifth leading cause of cancer death in men and the sixth in women, and the incidence increases yearly $(27,28)$. The 


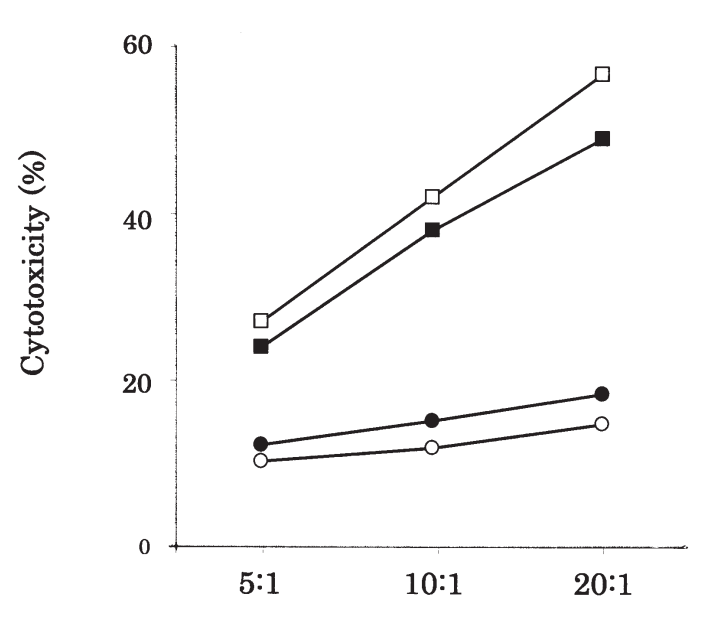

Effector to target cell ratio

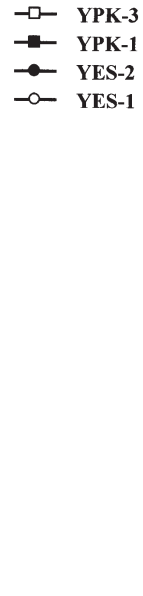

Figure 1. Cytotoxicity of CTLs induced from a healthy volunteer with the HLA-A phenotype 24/26. CTLs were stimulated by the MUC1-expressing human pancreatic cancer cell line, YPK-1 (HLA-A 24/02, MUC1-positive). Target cell lines were YPK-1, YPK-3 (pancreatic cancer, HLA-A 02/01, MUC1-positive), YES-2 (esophageal cancer, HLA-A 24/-, MUC1-negative) and YES-1 (esophageal cancer, HLA-A 02/01, MUC1-negative). Induced CTLs were cytotoxic against MUC1-expressing pancreatic cancer cell lines regardless of the HLA-A phenotype. Low cytotoxicity was observed in MUC1-negative esophageal cancer cell lines. Cytotoxicity was MHCunrestricted and clearly decreased with the decreasing effector cell number.

prognosis is very poor, $80 \%$ of patients are not eligible for surgical resection because of local spread or metastatic disease at the time of diagnosis. Even with curative surgery, MST does not exceed 2 years, with a 5-year survival of $15-25 \%$ (29-32). New treatment strategies are necessary to improve the outcome of patients with PC.

We have reported on the partial effectiveness of AIT with CTLs induced from tumor-infiltrating (TILs) or peripheral lymphocytes stimulated by autotumor cells in unresectable and in recurrent $\mathrm{PC}$, and on the ineffectiveness of AIT with LAK cells (11). However, AIT with CTLs stimulated by autologous tumors showed limited feasibility. It is technically difficult to isolate and expand autologous tumor cells of most histological tumor types, including PC. In addition, CTLs induced by autologous tumors are used as therapies for individual patients and cannot generalized to all patients with the same type of cancer. To overcome these limitations, we developed an AIT with CTLs stimulated by a MUC1expressing human PC cell line.

MUC1 is a target antigen for tumor-reactive CTLs from pancreatic, breast and ovarian cancers and multiple myeloma (17,33). MUC1-reactive T cells from patients with breast cancer, PC or multiple myeloma directly recognize MUC1 in an MHC-unrestricted manner (18,19,33-39). However, there is increasing evidence from mouse and human studies that $\mathrm{T}$ cells induced against the MUC1 protein can be MHCrestricted (40-45). We induced CTLs with a PC cell line expressing a high level of MUC1 and YPK-1 (25). Blocking assays showed that the anti-tumor activity of these cells was strongly inhibited by anti-CD3 or -CD8 mAbs, but not by anti-class I mAbs, indicating that these cells contain CTLs
Table V. Changes of lymphocyte subsets before and after the culture of PBMCs.

\begin{tabular}{|c|c|c|c|}
\hline Subset & Before (\%) & After $(\%)$ & P-values \\
\hline CD3 & $36.7 \pm 10.1$ & $77.0 \pm 15.0$ & $\mathrm{P}<0.05$ \\
\hline CD4 & $42.1 \pm 9.9$ & $52.1 \pm 10.6$ & $\mathrm{P}<0.05$ \\
\hline CD8 & $28.2 \pm 9.0$ & $28.5 \pm 11.6$ & NS \\
\hline $\mathrm{CD} 20$ & $14.2 \pm 8.0$ & $7.2 \pm 4.8$ & NS \\
\hline $\mathrm{CD} 25$ & $20.1 \pm 8.3$ & $14.0 \pm 8.7$ & $\mathrm{P}<0.05$ \\
\hline CD56 & $24.0 \pm 10.6$ & $14.3 \pm 6.6$ & $\mathrm{P}<0.05$ \\
\hline HLA-DR & $15.8 \pm 6.4$ & $10.4 \pm 6.7$ & $\mathrm{P}<0.05$ \\
\hline $\begin{array}{l}\text { Tsi } \\
\left(\mathrm{TQ} 1^{+} / \mathrm{CD}_{4}{ }^{+}\right)\end{array}$ & $32.7 \pm 7.6$ & $41.7 \pm 10.0$ & $\mathrm{P}<0.05$ \\
\hline $\begin{array}{l}\text { Th } \\
\left(\mathrm{TQ} 1 / \mathrm{CD}^{+}\right)\end{array}$ & $9.4 \pm 5.2$ & $10.5 \pm 5.8$ & NS \\
\hline $\begin{array}{l}\text { Ts } \\
\left(\mathrm{CD}^{+} / \mathrm{CDllb}^{-}\right)\end{array}$ & $7.2 \pm 4.0$ & $1.5 \pm 1.6$ & $\mathrm{P}<0.05$ \\
\hline $\begin{array}{l}\text { Tc } \\
\left(\mathrm{CD}^{+} / \mathrm{CD} \mathrm{llb}^{+}\right)\end{array}$ & $21.1 \pm 8.1$ & $27.1 \pm 10.8$ & $\mathrm{P}<0.05$ \\
\hline
\end{tabular}

Tsi, suppressor-inducer T ; Th, helper T ; Ts, suppressor T and Tc, cytotoxic T cells. Each specimen was 19 pairs derived from 6 patients who had undergone pancreatectomy. NS, non-significant.

and that the cytotoxicity was MHC-unrestricted. The stimulated cells showed a strong cytotoxicity against MUC1expressing PC and the breast cancer cell lines but not against non-MUC1- expressing cell lines. Cytotoxicity against YPK-1 cells treated with anti-MUC1 mAb was greatly decreased. Taken together, these data indicate that induced CTLs kill target cells in a MUC1-specific and MHC-unrestricted manner. These results are consistent with those of Jerome et al (18). The mechanism of cytotoxicity in an MHC-unrestricted manner is poorly understood. Induced cells contain not only CTLs recognizing MUC1 but also LAK, natural killer (NK) and natural killer T (NKT) cells. However, a subset analysis of induced cells showed that the proportion of cytotoxic T cells was high. CTLs recognizing MUC1 may be a predominant cell type among induced cells.

We have reported that invading or metastatic PC cells express MUC1 all along the cell membrane (46). We therefore hypothesized that these CTLs may be used therapeutically for PC. We treated 8 patients with unresectable PC with AIT using these CTLs. Although AIT did not improve survival, none of the 5 patients with unresectable PC and without liver metastasis developed liver metastasis. No adverse effects were observed. It has been reported that the postoperative survival time for PC patients with hepatic recurrence is significantly shorter than that of patients with local recurrence $(47,48)$. Our clinical results suggest that AIT with MUC1-specific and MHC-unrestricted CTLs may prevent the liver metastasis of PC. We therefore applied this 


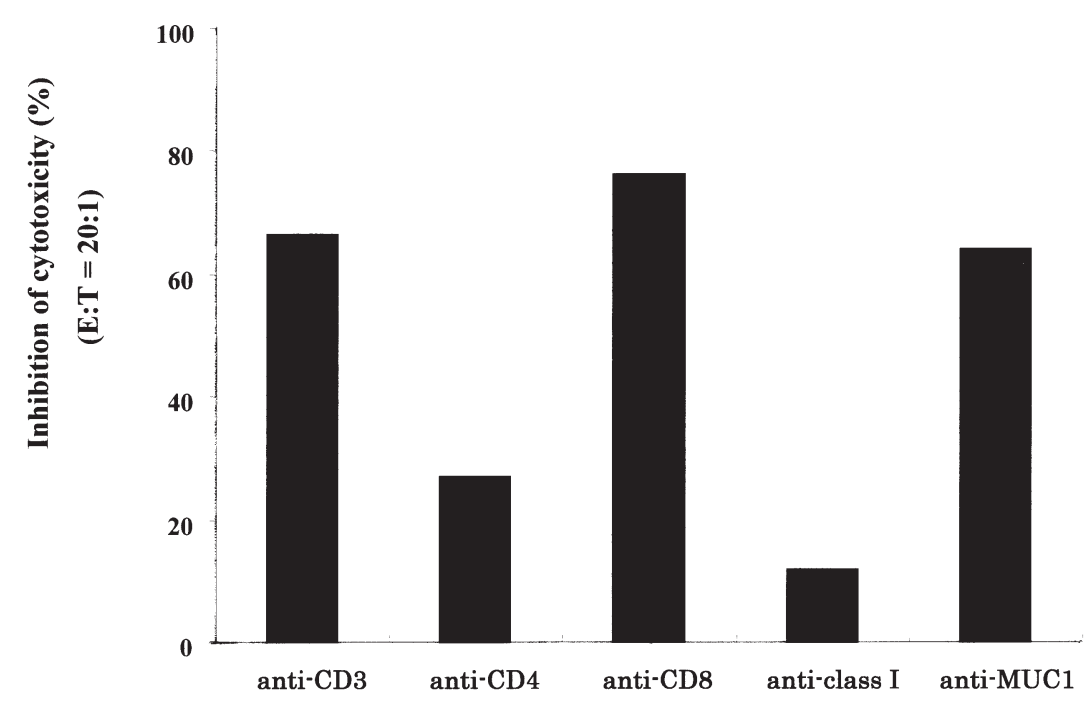

Antibodies

Figure 2. Inhibition of CTL-induced cytotoxicity by monoclonal antibodies (mAb). Anti-CD3 or -CD8 mAb strongly inhibited cytotoxicity against YPK-1 cells, whereas anti-class I mAb showed no inhibition. YPK-1 cells treated with anti-MUC1 mAb also showed a low cytotoxicity.

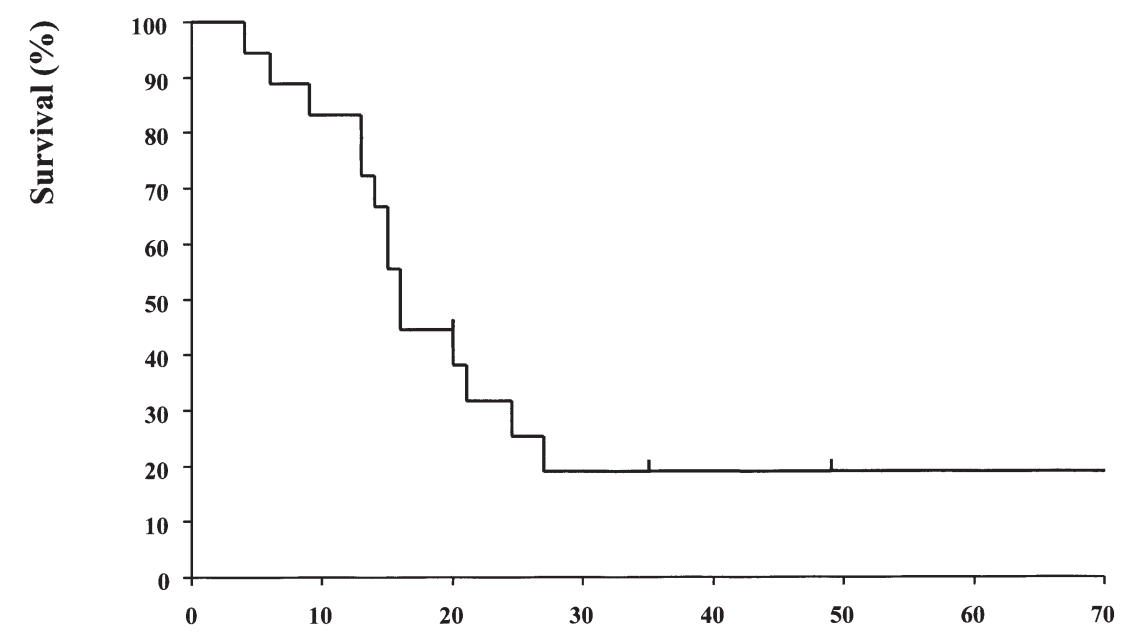

Months after curative resection

Figure 3. Kaplan-Meier estimates of the cumulative survival after curative resection in patients with pancreatic cancer (18 patients). The 1-, 2- and 3-year survival rates were $83.3,32.4$ and $19.4 \%$, respectively.

AIT as an adjuvant therapy in PC patients who underwent curative resection because hepatic recurrence is an important factor for postsurgical survival. It has been reported that occult liver metastasis is often present in PC patients at the time of pancreatectomy $(49,50)$, suggesting that an adjuvant therapy for PC should be performed in the early postoperative period. We therefore administered induced CTLs intravenously within 7 days after surgery. CTLs were re-induced and administered several times after the patient's recovery.Of the patients treated with this AIT, 19 out of 20 showed no hepatic recurrence regardless of the HLA phenotype. Kobari et al (51) reported suppressed liver metastasis with AIT with the intraportal infusion of LAK cells after pancreatectomy. However, we did not find efficacy of LAK therapy for PC (11). It has been reported that intravenously injected peripheral blood lymphocytes and LAK cells are taken up mostly by the liver and spleen (52). Thus, CTLs may distribute mainly to the liver. The mechanism whereby intravenous administration of CTLs suppress liver metastasis remains to be elucidated.

In our clinical study, MST of adjuvant immunotherapy with induced CTLs was 17.8 months. The 1-, 2- and 3-year survival rates after resection were $83.3,32.4$ and $19.4 \%$, respectively. Adjuvant immunotherapy proved to be better 
than surgery alone, which our group had performed in our institute before 1996 (MST: 14.0 months, 1-, 2- and 3-year survival rates after resection were 60.6, 21.2 and $12.9 \%$; data not shown). The MST of AIT with CTLs was similar to other adjuvant chemotherapies and chemoradiotherapies (1,53-56). Some clinical trials of adjuvant chemotherapy for patients with resectable PC using gemcitabine were reported $(57,58)$, and it may be better than other chemotherapies. However, adjuvant chemotherapies and chemoradiotherapies including gemcitabine frequently cause severe toxicities. The advantage of AIT using CTLs is that treatment can be completed within 2 months after surgery and even after discharge from the hospital, treatment can be continued with no complications. New treatment strategies are necessary to suppress local recurrence and to further increase the survival time obtained with AIT.

In conclusion, CTLs stimulated by a MUC1-expressing human PC cell line show strong cytotoxicity in a MUC1specific and MHC-unrestricted manner. AIT with these CTLs significantly suppresses the postsurgical hepatic recurrence of PC. Therefore, this immunotherapy may be useful as an adjuvant treatment.

\section{References}

1. Hirata K, Sato T, Mukaiya M, Yamashiro K, Kimura M, Sasaki K and Denno R: Results of 1001 pancreatic resections for invasive ductal adenocarcinoma of the pancreas. Arch Surg 132: 771-776, 1997.

2. Gudjonsson B: Cancer of the pancreas. 50 years of surgery. Cancer 60: 2284-2303, 1987.

3. Warshaw AL and Swanson RS: Pancreatic cancer in 1988. Possibilities and probabilities. Ann Surg 208: 541-553, 1988.

4. Schulz G, Buchler M, Muhrer KH, Klapdor R, Kubel R, Harthus HP, Madry $\mathrm{N}$ and Bosslet K: Immunotherapy of pancreatic cancer with monoclonal antibody BW 494. Int J Cancer (Suppl 2): S89-S94, 1988

5. Tempero MA, Haga Y, Sivinski C, Steplewski Z, Kay HD and Pour P: Immunotherapy with monoclonal antibody (Mab) in pancreatic adenocarcinoma. Int J Pancreatol 9: 125-134, 1991.

6. Buchler M, Friess H, Schultheiss KH, Gebhardt C, Kubel R, Muhrer KH, Winkelmann M, Wagener T, Klapdor R and Kaul M: A randomized controlled trial of adjuvant immunotherapy (murine monoclonal antibody 494/32) in resectable pancreatic cancer. Cancer 68: 1507-1512, 1991

7. Friess H, Gassmann M and Buchler MW: Adjuvant therapy of pancreatic cancer using monoclonal antibodies and immune response modifiers. Int J Pancreatol 21: 43-52, 1997.

8. Hersh EM, Metch BS, Muggia FM, Brown TD, Whitehead RP, Budd GT, Rinehart JJ, Crawford ED, Bonnet JD and Behrens BC: Phase II studies of recombinant human tumor necrosis factor alpha in patients with malignant disease: a summary of the Southwest Oncology Group experience. J Immunother 10: 426-431, 1991

9. Yamamoto K, Mine T, Katagiri K, Suzuki N, Kawaoka T, Ueno T, Matsueda S, Yamada A, Itoh K, Yamana $\mathrm{H}$ and Oka M: Immunological evaluation of personalized peptide vaccination for patients with pancreatic cancer. Oncol Rep 13: 875-883, 2005.

10. Sparano JA, Fisher RI, Weiss GR, Margolin K, Aronson FR, Hawkins MJ, Atkins MB, Dutcher JP, Gaynor ER and Boldt DH: Phase II trials of high-dose interleukin-2 and lymphokineactivated killer cells in advanced breast carcinoma and carcinoma of the lung, ovary, and pancreas and other tumors. J Immunother Emphasis Tumor Immunol 16: 216-223, 1994.

11. Oka M, Suzuki M, Hazama S and Suzuki T: Adoptive immunotherapy for unresectable or recurrent pancreatic cancer, using lymphokine-activated killer cells or cytotoxic T cells. J Hep Pancr Surg 2: 163-167, 1994.

12. Devine PL and McKenzie IF: Mucins: structure, function, and associations with malignancy. Bioessays 14: 619-625, 1992.
13. Duraisamy S, Ramasamy S, Kharbanda S and Kufe D: Distinct evolution of the human carcinoma-associated transmembrane mucins, MUC1, MUC4, and MUC16. Gene 373: 28-34, 2006.

14. Gendler SJ, Lancaster CA, Taylor-Papadimitriou J, Duhig T, Peat N, Burchell J, Pemberton L, Lalani EN and Wilson D: Molecular cloning and expression of human tumor-associated polymorphic epithelial mucin. J Biol Chem 265: 15286-15293, 1990.

15. Hanisch FG, Stadie TR, Deutzmann F and Peter-Katalinic J: MUC1 glycoforms in breast cancer-cell line T47D as a model for carcinoma-associated alterations of 0-glycosylation. Eur J Biochem 236: 318-327, 1996.

16. Burchell J, Gendler S, Taylor-Papadimitriou J, Girling A, Lewis A, Millis R and Lamport D: Development and characterization of breast cancer reactive monoclonal antibodies directed to the core protein of the human milk mucin. Cancer Res 47: 5476-5482, 1987

17. Barnd DL, Lan MS, Metzgar RS and Finn OJ: Specific, major histocompatibility complex-unrestricted recognition of tumorassociated mucins by human cytotoxic T cells. Proc Natl Acad Sci USA 86: 7159-7163, 1989.

18. Jerome KR, Barnd DL, Bendt KM, Boyer CM, Taylor-Papadimitriou J, McKenzie IFC, Bast RC and Finn OJ: Cytotoxic T-lymphocytes derived from patients with breast adenocarcinoma recognize an epitope present on the protein core of a mucin molecule preferentially expressed by malignant cells. Cancer Res 51: 2908-2916, 1991.

19. Ioannides CG, Fisk B, Jerome KR, Irimura T, Wharton JT and Finn OJ: Cytotoxic $T$ cells from ovarian malignant tumors can recognize polymorphic epithelial mucin core peptides. J Immunol 151: 3693-3703, 1993.

20. Byrd JC, Ho JJ, Lamport DT, Ho SB, Siddiki B, Huang J, Yan PS and Kim YS: Relationship of pancreatic cancer apomucin to mammary and intestinal apomucins. Cancer Res 51: 1026-1033, 1991.

21. Osako M, Yonezawa S, Siddiki B, Huang J, Ho JJ, Kim YS and Sato E: Immunohistochemical study of mucin carbohydrates and core proteins in human pancreatic tumors. Cancer 71: 2191-2199, 1993.

22. Hollingsworth MA, Strawhecker JM, Caffrey TC and Mack DR: Expression of MUC1, MUC2, MUC3 and MUC4 mucin mRNAs in human pancreatic and intestinal tumor cell lines. Int J Cancer 57: 198-203, 1994.

23. Terada T, Ohta T, Sasaki M, Nakanuma Y and Kim YS Expression of MUC apomucins in normal pancreas and pancreatic tumours. J Pathol 180: 160-165, 1996.

24. Masaki Y and Oka M: Adoptive immunotherapy for pancreatic cancer, using MUC1 specific CTL (in Japanese). Jpn J Cancer Chemother 23: 1679-1680, 1996.

25. Yamamoto K, Yahara N, Gondo T, Ishihara T and Oka M: Establishment and characterization of a new human pancreatic cancer cell line, YPK-1. Bull Yamaguchi Med Sch 49: 33-42, 2002.

26. Sobin LH and Wittekind C: TNM Classification of Malignant Tumours. 6th edition UICC, Wiley-Liss, New York, pp93-96, 2002.

27. Matsuno S, Egawa S, Fukuyama S, Motoi F, Sunamura M, Isaji S, Imazumi T, Okada S, Kato H, Suda K, Nakao A, Hiraoka T, Hosotani R and Takeda K: Pancreatic cancer registry in Japan. 20 years of experience. Pancreas 28: 219-230, 2004.

28. Isaji S, Kawarada Y and Uemoto S: Classification of pancreatic cancer. Comparison of Japanese and UICC classifications. Pancreas 28: 231-234, 2004.

29. Connolly MM, Dawson PJ, Michelassi F, Moossa AR and Lowenstein F: Survival in 1001 patients with carcinoma of the pancreas. Ann Surg 206: 366-373, 1987.

30. Yeo CJ, Cameron JL, Sohn TA, Lillemoe KD, Pitt HA, Talamini MA, Hruban RH, Ord SE, Sauter PK, Coleman J, Zahurak ML, Grochow LB and Abrams RA: Six hundred fifty consecutive pancreaticoduodenectomies in the 1990s: pathology, complications, and outcomes. Ann Surg 226: 248-257, 1997.

31. Pedrazzoli S, DiCarlo V, Dionigi R, Mosca F, Pederzoli P, Pasquali C, Kloppel G, Dhaene K and Michelassi F: Standard versus extended lymphadenectomy associated with pancreatoduodenectomy in the surgical treatment of adenocarcinoma of the head of the pancreas: a multicenter, prospective, randomized study. Lymphadenectomy Study Group. Ann Surg 228: 508-517, 1998. 
32. Wagner M, Redaelli C, Lietz M, Seiler CA, Friess H and Buchler MW: Curative resection is the single most important factor determining outcome in patients with pancreatic adenocarcinoma. Br J Surg 91: 586-594, 2004.

33. Takahashi T, Makiguchi Y, Hinoda Y, Kakiuchi H, Nakagawa N, Imai $\mathrm{K}$ and Yachi A: Expression of MUC1 on myeloma cells and induction of HLA-unrestricted CTL against MUC1 from a multiple myeloma patient. J Immunol 153: 2102-2109, 1994.

34. Apostolopoulos V and McKenzie IF: Cellular mucins: targets for immunotherapy. Crit Rev Immunol 14: 293-309, 1994.

35. Finn OJ, Jerome KR, Henderson RA, Pecher G, Domenech N, Magarian-Blander J and Barratt-Boyes SM: MUC-1 epithelial tumor mucin-based immunity and cancer vaccines. Immunol Rev 145: 61-89, 1995.

36. Kotera Y, Fontenot JD, Pecher G, Metzgar RS and Finn OJ: Humoral immunity against a tandem repeat epitope of human mucin MUC-1 in sera from breast, pancreatic, and colon cancer patients. Cancer Res 54: 2856-2860, 1994.

37. Noto H, Takahashi T, Makiguchi Y, Hayashi T, Hinoda Y and Imai K: Cytotoxic T lymphocytes derived from bone marrow mononuclear cells of multiple myeloma patients recognize an underglycosylated form of MUC1 mucin. Int Immunol 9: 791-798, 1997.

38. Agrawal B, Krantz MJ, Reddish MA and Longenecker BM: Cancer-associated MUC1 mucin inhibits human T-cell proliferation, which is reversible by IL-2. Nat Med 4: 43-49, 1998.

39. Karanikas V, Hwang LA, Pearson J, Ong CS, Apostolopoulos V, Vaughan H, Xing PX, Jamieson G, Pietersz G, Tait B, Broadbent R, Thynne G and Mckenzie IF: Antibody and T cell responses of patients with adenocarcinoma immunized with mannan-MUC1 fusion protein. J Clin Invest 100: 2783-2792, 1997.

40. Domenech N, Henderson RA and Finn OJ: Identification of an HLA-A11-restricted epitope from the tandem repeat domain of the epithelial tumor antigen mucin. J Immunol 155: 4766-4774, 1995.

41. Agrawal B, Reddish MA and Longenecker BM: In vitro induction of MUC-1 peptide-specific type 1 T lymphocyte and cytotoxic $\mathrm{T}$ lymphocyte responses from healthy multiparous donors. J Immunol 157: 2089-2095, 1996.

42. Apostolopoulos V, Haurum JS and McKenzie IF: MUC1 peptide epitopes associated with five different H-2 class I molecules. Eur J Immunol 27: 2579-2587, 1997.

43. Apostolopoulos V, Karanikas V, Haurum JS and McKenzie IF: Induction of HLA-A2-restricted CTLs to the mucin 1 human breast cancer antigen. J Immunol 159: 5211-5218, 1997.

44. Reddish M, MacLean GD, Koganty RR, Kan-Mitchell J, Jones V, Mitchell MS and Longenecker BM. Anti-MUC1 class I restricted CTLs in metastatic breast cancer patients immunized with a synthetic MUC1 peptide. Int J Cancer 76: 817-823, 1998.

45. Brossart P, Heinrich KS, Stuhler G, Behnke L, Reichardt VL, Stevanovic S, Muhm A, Rammensee HG, Kanz L and Brugger W: Identification of HLA-A2-restricted T-cell epitopes derived from the MUC1 tumor antigen for broadly applicable vaccine therapies. Blood 93: 4309-4317, 1999.

46. Masaki Y, Oka M, Ogura Y, Ueno T, Nishihara K, Tangoku A, Takahashi M, Yamamoto M and Irimura T: Sialylated MUC1 mucin expression in normal pancreas, benign pancreatic lesions, and pancreatic ductal adenocarcinoma. Hepatogastroenterology 46: 2240-2245, 1999.
47. Sperti C, Pasquali C, Piccoli A and Pedrazzoli S: Recurrence after resection for ductal adenocarcinoma of the pancreas. World $\mathbf{J}$ Surg 21: 195-200, 1997.

48. Westerdahl J, Andren-Sandberg A and Ihse I: Recurrence of exocrine pancreatic cancer - local or hepatic? Hepatogastroenterology 40: 384-387, 1993.

49. Inoue S, Nakao A, Kasai Y, Harada A, Nonami T and Takagi H: Detection of hepatic micrometastasis in pancreatic adenocarcinoma patients by two-stage polymerase chain reaction/ restriction fragment length polymorphism analysis. Jpn J Cancer Res 86: 626-630, 1995

50. Amikura K, Kobari M and Matsuno S: The time of occurrence of liver metastasis in carcinoma of the pancreas. Int J Pancreatol 17: 139-146, 1995.

51. Kobari M, Egawa S, Shibuya K, Sunamura M, Saitoh K and Matsuno S: Effect of intraportal adoptive immunotherapy on liver metastases after resection of pancreatic cancer. Br J Surg 87: 43-48, 2000

52. Marincola FM, Drucker BJ, Keeling CA, Siao DY, Starnen HF, Goodwin DA and Holder WD: The in vivo distribution of human peripheral blood lymphocytes and lymphokine-activated killer cells adoptively transferred in human pancreatic cancerbearing nude mice. Surgery 105: 79-85, 1989.

53. Yeo CJ, Abrams RA, Grochow LB, Sohn TA, Ord SE, Hruban RH, Zahurak ML, Dooley WC, Coleman J, Sauter PK, Pitt HA, Lillemoe KD and Cameron JL: Pancreaticoduodenectomy for pancreatic adenocarcinoma: postoperative adjuvant chemoradiation improves survival. A prospective, single-institution experience. Ann Surg 225: 621-636, 1997.

54. Klinkenbijl JH, Jeekel JJ, Sahmoud T, Pel RV, Couvreur ML, Veenhof CH, Arnaud JP, Gonzalez DG, Wit LT, Hennipman A and Wils J: Adjuvant radiotherapy and 5-fluorouracil after curative resection of cancer of the pancreas and periampullary region: phase III trial of the EORTC gastrointestinal tract cancer cooperative group. Ann Surg 230: 776-784, 1999.

55. Neoptolemos JP, Dunn JA, Stocken DD, Almomd J, Link K, Beger H, Bassi C, Falconi M, Pederzoli P, Dervenis C, Fernandez-Cruz L, Lacaine F, Pap A, Spooner D, Kerr DJ and Friess H: Adjuvant chemoradiotherapy and chemotherapy in resectable pancreatic cancer: a randomised controlled trial. Lancet 358: 1576-1585, 2001.

56. Neoptolemos JP, Stocken DD, Friess H, Bassi C, Dunn JA, Hickey H, Beger H, Fernandez-Cruz L, Dervenis C, Lacaine F, Falconi M, Pederzoli P, Pap A, Spooner D, Kerr DJ and Buchler MW: A randomized trial of chemoradiotherapy and chemotherapy after resection of pancreatic cancer. N Eng J Med 350: 1200-1210, 2004.

57. Oettle H, Post S, Neuhaus P, Gellert K, Langrehr J, Ridwelski K, Schramm H, Fahlke J, Zuelke C, Burkart C, Gutberlet K, Kettner E, Schmalenberg H, Weigang-Koehler K, Bechstein WO, Niedergethmann M, Schmidt-Wolf I, Roll L, Doerken B and Riess H: Adjuvant chemotherapy with gemcitabine vs observation in patients undergoing curative-intent resection of pancreatic cancer: a randomized controlled trial. JAMA 297: 267-277, 2007.

58. Kurosaki I and Hatakeyama K: The clinical efficacy of adjuvant systemic chemotherapy with gemcitabine in node-positive pancreatic cancer. Hepatogastroenterology 51: 634-637, 2004. 